\title{
Sex Identification and Development of Single Blastomeres from 2-cell Mouse Embryos
}

\author{
Meiwei XIAN, Kazuo MORIWAKI ${ }^{1)}$ and Yutaka TOYODA \\ Department of Animal Pathology, Institute of \\ Medical Science, University of Tokyo, Tokyo \\ 108 and ${ }^{1)}$ National Institute of Genetics, \\ Mishima 411, Japan
}

\begin{abstract}
Single blastomeres were isolated from 2-cell mouse embryos and analysed for their sex by using partially deleted Y-chromosome as a marker. Sex identification of $83 \%$ of the embryos was achieved with conventionally Giemsa-stained chromosome preparations. The other half-embryos were cultured individually or recombined with another half-embryo of the same sex, and were transferred to pseudopregnant recipient females. Six percent of the half and $18 \%$ of the recombined embryos developed into live fetuses. The sex of these fetuses was identical with that determined prior to embryo transfer. Sex analysis in this way was accurate and early enough to allow utilization of sex-known embryos for development and sex differentiation studies at the cleavage stage.

Key words: Partially deleted Y-chromosome, Single blastomere, Karyotyping, Development of sexknown embryos.
\end{abstract}

(J. Reprod. Dev. 38: 15-21, 1992)

$\mathbf{N}$ umerous attempts have been made to study the genetic traits of preimplantation embryos. One trait that has received much attention is sex. The mammalian $\mathrm{Y}$ chromosome plays a crucial part in sex determination: an embryo that inherits a $\mathrm{Y}$ chromosome develops as a male whereas an embryo lacking a $\mathrm{Y}$ chromosome develops as a female [1]. In eutherian mammals, evidence suggests that sex determination is equivalent to testis determination [2]. The sex determining gene(s) on the $\mathrm{Y}$ chromosome induces testicular development, and subsequent male sexual differentiation is a consequence of the hormonal products of the testis [3]. The Y-encoded testisdetermining gene has been designated TDF (testisdetermining factor) in humans and $T d y$ (testisdetermining-Y chromosome) in mouse $[3,4]$. It is likely that many different genes are required for both male and female sex differentiation, and it is

Accepted for Publication: June 28, 1991

Correspondence: Y. Toyoda assumed the $T d y$ must act within the context of the other regulatory molecules. There is no doubt that sexing preimplantation embryos facilitates the utilization of sex-known embryos for further study and understanding of the mechanism of sex determination and differentiation.

In the present study, we attempted to sex single blastomeres separated from 2-cell mouse embryos with a partially deleted $\mathrm{Y}$ chromosome as a marker, and the observation on development of the sex-known single blastomeres was conducted.

\section{Materials and Methods}

Mice

The mice used in the experiments were 8-22week-old mature B10.BR-Y ${ }^{\text {del }}$ males, 4-week-old C57BL/6N (B6) and mature ICR females. B10·BR$\mathrm{Y}^{\text {del }}\left(\mathrm{Y}^{\text {del }}\right)$ mouse was first established as a mutant of B10.BR mouse at the National Institute of 
Genetics of Japan [5]. This mouse was introduced to the Department of Animal Pathology, Institute of Medical Science, University of Tokyo in 1988 and maintained by brother-sister mating. Female B6 and ICR mice were used as the oocyte donor and recipient mouse respectively. Both of these mice were purchased from Clea Japan Inc.

\section{Treatment of spermatozoa with Percoll solution}

Sperm suspensions were prepared by releasing the contents of each pair of cauda epididymidis into $0.8 \mathrm{ml}$ of $\mathrm{TYH}$ medium [6] overlaid by mineral oil, and incubated at $37 \mathrm{C}$ with $5 \% \mathrm{CO}_{2}$ in air for $30 \mathrm{~min}$ to allow dispersal of the spermatozoa. $0.5 \mathrm{ml}$ of the sperm suspension was loaded onto the gradient of Percoll (Pharmacia Fine Chemicals, Uppsala, Sweden) in TYH and centrifuged at $250 \times \mathrm{g}$ for $10 \mathrm{~min}$ at room temperature. The sperm-rich bottom fraction was transferred to another tube and overlaid with $0.5 \mathrm{ml}$ of fresh TYH medium to allow the spermatozoa to swim up to the added TYH medium during $30 \mathrm{~min}$ incubation. The spermatozoa, which swam up and will be referred to as Percoll-treated spermatozoa hereinafter, were used for in vitro fertilization.

\section{In vitro fertilization}

Four-week-old $\mathrm{C} 57 \mathrm{BL} / 6 \mathrm{~N}$ female mice were induced to superovulate with i.p. injections of 5 i.u. pregnant mares' serum gonadotropin (PMSG) (Sankyo Zoki Co. Japan) and 48 h later 5 i.u. human chorionic gonadotropin (hCG) (Sankyo Zoki Co. Japan). Unfertilized, cumulus-intact eggs were recovered 14-16 $\mathrm{h}$ after the hCG injection and released directly to $0.2 \mathrm{ml}$ droplets of TYH medium, which contained spermatozoa in concentrations of $1-5 \times 10^{5}$ cells $/ \mathrm{ml}$. All droplets of the medium were overlaid with mineral oil and the eggs and the spermatozoa were incubated at $37 \mathrm{C}$ in an atmosphere of $5 \% \mathrm{CO}_{2}$ in air for $5-6 \mathrm{~h}$. The eggs possessing a second polar body and both male and female pronuclei were considered fertilized and were cultured in Whitten's medium (WM) [7] containing $0.1 \mathrm{mM}$ EDTA [8] after washing several times.

\section{Separation of blastomeres at the 2-cell stage}

About $30 \mathrm{~h}$ post-insemination, 2-cell embryos were treated with $0.5 \%$ pronase (Kaken Seiyaku Co., Tokyo) in Hepes-WM for 3-5 min to remove zona pellucida and washed by passage through several drops of WM. Blastomere pairs were obtained by gentle pipetting the zona-free 2-cell embryos with a micropipette with an internal diameter of $70-100 \mu \mathrm{m}$. One of the blastomeres was subjected to karyotypic analysis, and the other was transferred to a WM droplet for embryo culture.

Karyotyping and sexing of single blastomeres isolated from 2-cell embryos

Each isolated blastomere was transferred to a 10 $\mu l$ drop of Colcemid solution $(0.06 \mu \mathrm{g} / \mathrm{ml}$ in $\mathrm{WM}$, Life Technologies Inc. Grand Island, U.S.A.) and incubated overnight to stop mitosis. The blastomere was then transferred to a hypotonic solution of $40 \%$ fetal calf serum (FCS, GIBCO, Grand Island, NY, U.S.A.) and treated for 10-15 min. One blastomere at a time was placed on a clean slide, and 1-2 drops of a freshly prepared fixative mixture of 3:1 methanol:acetic acid were dropped onto the blastomere. The slides obtained were conventionally stained with $2 \%$ Giemsa solution (E. Merck) in phosphate buffer at pH $6.8[9,10]$.

Sex analysis of the blastomeres was performed by examining the chromosome preparations under a microscope. The blastomeres bearing 40 chromosomes including a partially deleted Ychromosome, which appeared to be only about half the size of the normal one, were classified as males and those without the deleted Ychromosome were considered to be females.

\section{Aggregation of two sexed half-embryos}

Each of 2 male or female half-embryos developed from single blastomeres of 2-cell embryos was placed into a drop of $10 \mu \mathrm{l}$ phytohemagglutinin P solution (PHA, $50 \mu \mathrm{g} / \mathrm{ml}$ in WM. Difco Laboratories, Detroit, Michigan, U.S.A.), and aggregated together with 2 well polished, micro glass needles, just before compaction occurred. The recombined embryos were incubated at $37 \mathrm{C}$ for 10-15 min and washed several times prior to embryo culture.

\section{Embryo culture and transfer}

All treated embryos were cultured individually in drops of $10 \mu \mathrm{l} \mathrm{WM}$ containing $0.1 \mathrm{mM}$ EDTA, in an $60 \mathrm{~mm}$ plastic culture dish (Corning Inc. N.Y., U.S.A.). Since in preliminary experiments the highest viability of zona-free embryos was obtained when day 4 recipient mice were used, the 
blastocysts developed from single blastomeres and aggregated embryos were transferred into the uteri of ICR recipient mice (Clea Japan Inc.) on day 4 of pseudopregnancy under anesthesia with an i.p. injection of $2.5 \%$ Avertin [11]. Pseudopregnancy was induced by mating the females with vasectomized males, and the day on which female mice were found with vaginal plugs was counted as Day 1 . The recipient mice were killed by cervical dislocation on Day 18 of gestation and examined for live fetuses and implantation sites. The sex of the fetuses was diagnosed by examining their gonads under a dissecting microscope.

Determination of number of component blastomeres

At 72 and $96 \mathrm{~h}$ post-insemination, some of the half embryos were placed on clean slides, fixed with a fixative of 3:1 methanol:acetic acid and stained with 2\% Giemsa solution after 15-30 min hypotonic treatment in $0.8 \%$ trisodium citrate solution. The number of component blastomeres per embryo was determined by counting the nuclei under a microscope.

\section{Statistical analysis}

The results of the embryo transfer were analyzed by $\mathrm{X}^{2}$ test to determine the significance of differences between the developmental rate of the half and recombined embryos, and the male and female half-embryos. Student's $t$-test was used for testing the differences between average number of cells in the morulae and blastocyst stages in male and female half embryos.

\section{Results}

\section{In vitro fertilization}

All of the embryos were obtained from in vitro fertilization for exact evaluation of embryonic development and to facilitate the sex diagnosis. Among the 764 of the oocytes examined, 675 were fertilized, giving a $88 \%$ fertilization rate.
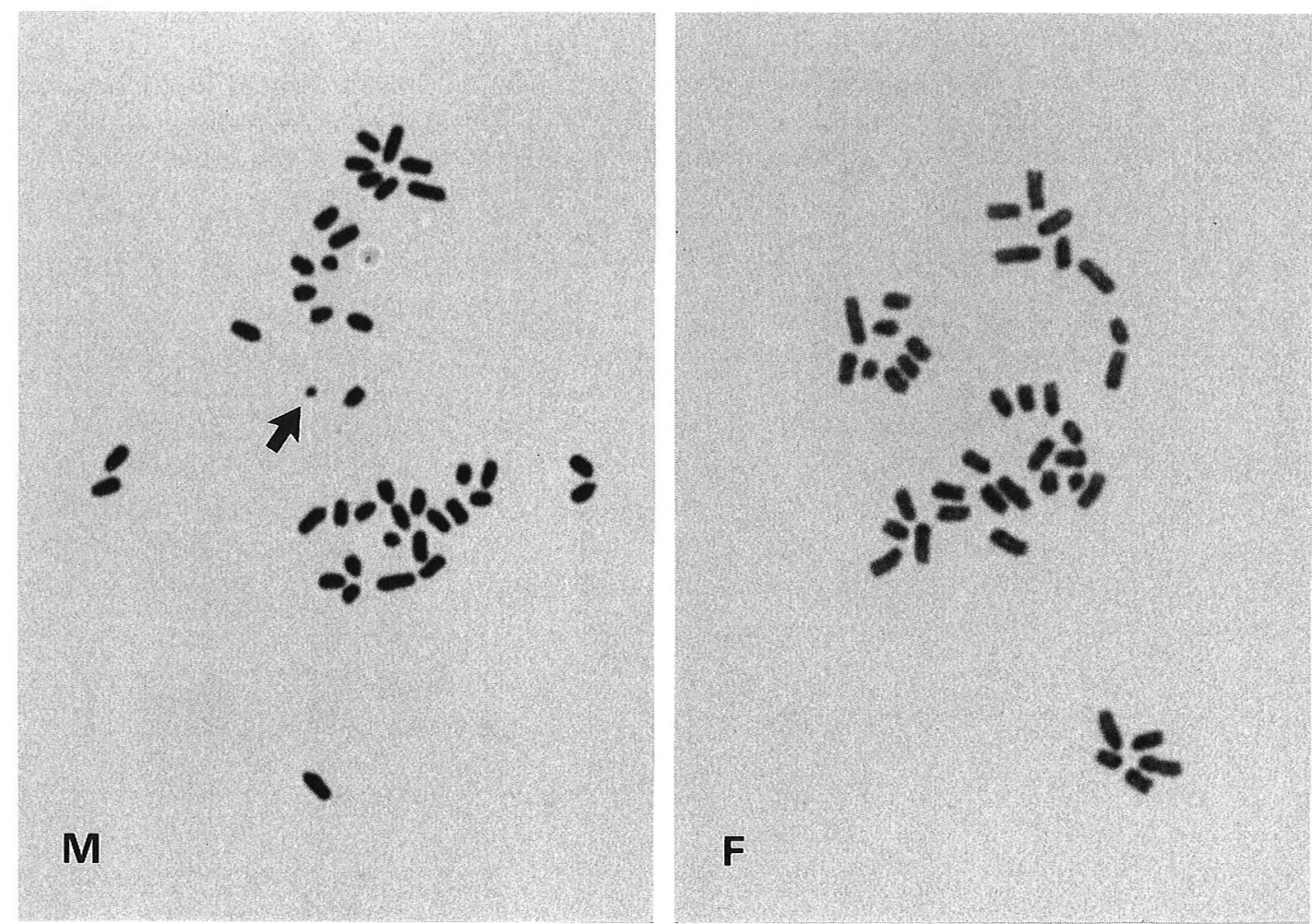

Fig. 1. The metaphase plates from single blastomeres of 2-cell embryos. (M) Male blastomere possessing a partially deleted Y chromosome (arrowed). (F) Blastomere without Y chromosome and classified as female. Reproduced at $1000 \times$. 
Table 1. Sexing of single blastomeres from 2-cell stage embryos by karyotyping analysis

\begin{tabular}{lcccccc}
\hline No & No and (\%) at & Polyploid & Analysable no. & \multicolumn{3}{c}{ Sex ratio } \\
\cline { 5 - 7 } scored & metaphase & & /diploid (\%) & Male & Female $\%$ of male \\
\hline 659 & $653(99)$ & $18(3 n), 1(4 n)$ & $528 / 634(83)$ & 281 & 247 & 53 \\
\hline
\end{tabular}

Sex determination was performed only with diploid blastomeres. The embryos possessing 40 chromosomes including a deleted Y-chromosome were classified as male. The others were considered to be female. Values are for 7 replicates.

Karyotyping and sexing single blastomeres separated from 2-cell embryos

Single blastomeres isolated from 2-cell stage embryos were subjected to karyotyping and sex analysis at 33-34 h after insemination. The blastomeres possessing 40 chromosomes including a deleted Y-chromosome were regarded as males and those without the deleted Y-chromosome were considered to be females (Fig. 1). The results are summarized in Table 1. Among the 659 preparations handled, 653 (99\%) blastomeres were undergoing mitotic division and all were in the metaphase. Of these blastomeres, 19 were polyploids including both $3 \mathrm{n}$ and $4 \mathrm{n}$ ones. The remaining 634 were classified as diploids, of which 8 possessed 39 or 41 chromosomes and thus were treated as unanalyzable diploids. Finally 528 (83\%)
Table 2. In vitro development of single blastomeres separated from 2-cell embryos

\begin{tabular}{cccc}
\hline \multirow{2}{*}{ No cultured } & \multicolumn{2}{c}{ No. and (\%) developed to } \\
\cline { 2 - 4 } & $\begin{array}{c}2 \text {-cell } \\
(48 \mathrm{~h})^{*}\end{array}$ & $\begin{array}{c}\text { Morula } \\
(72 \mathrm{~h})^{*}\end{array}$ & $\begin{array}{c}\text { Blastocyst } \\
(96 \mathrm{~h})^{*}\end{array}$ \\
\hline 413 & $389(94)$ & $360(87)$ & $339(82)$ \\
\hline
\end{tabular}

Separation of blastomeres was performed by pipetting the 2-cell embryos whose zonae pellucidae were removed with $0.5 \%$ Pronase solution. Each blastomere was cultured separately in a $10 \mu \mathrm{l} \mathrm{WM}$ drop. *Time after insemination. Values are for 5 replicates.

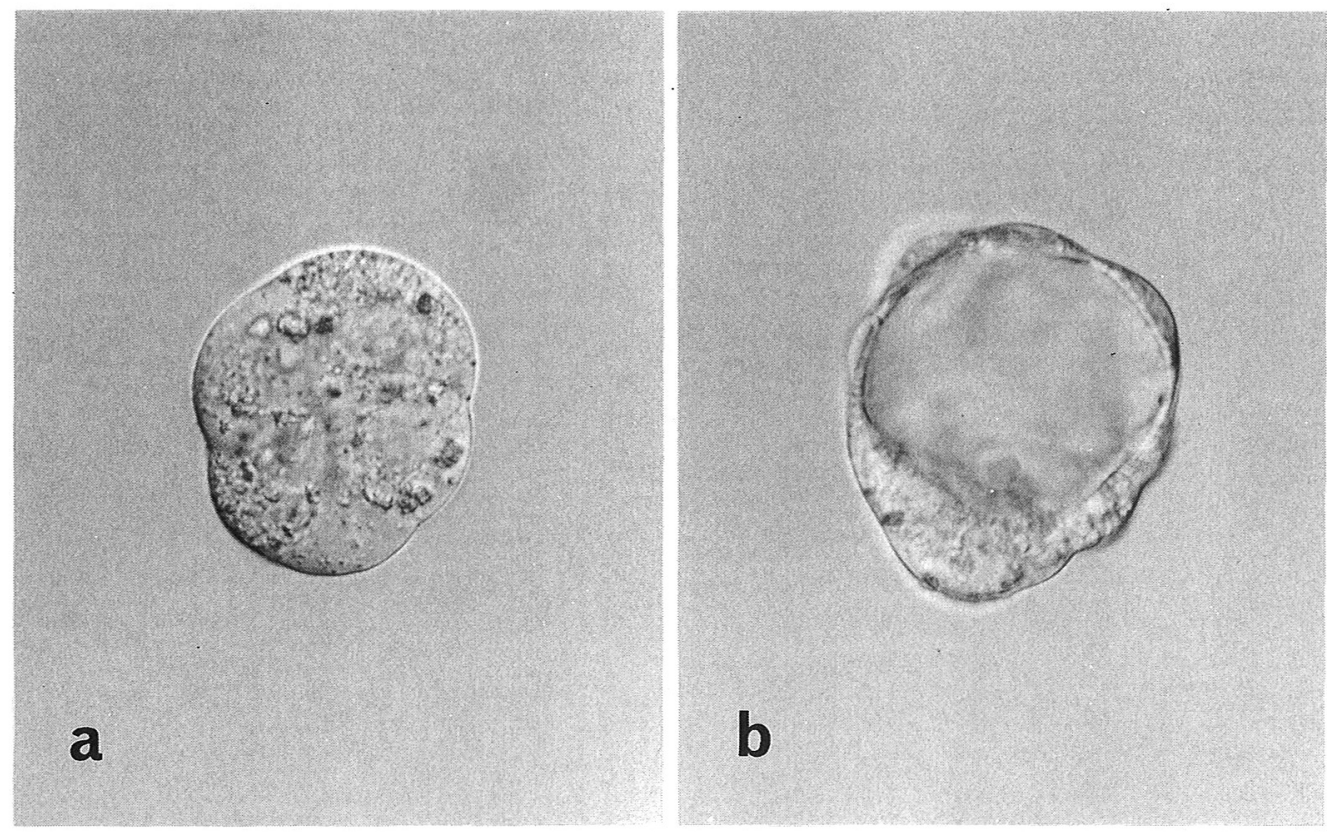

Fig. 2. Microphotographs of in vitro cultured embryos developed from single blastomeres in the 2-cell stage. (a) in the morula stage $72 \mathrm{~h}$ post-insemination. (b) in the blastocyst stage $96 \mathrm{~h}$ post-insemination. Reproduced at $500 \times$. 
Table 3. The viability of sex-known blastocysts after embryo transfer

\begin{tabular}{|c|c|c|c|c|c|c|c|}
\hline \multirow{2}{*}{$\begin{array}{l}\text { Sex of } \\
\text { embryos }\end{array}$} & \multirow{2}{*}{$\begin{array}{l}\text { No. of embryos } \\
\text { sexed and } \\
\text { transferred }\end{array}$} & \multirow{2}{*}{$\begin{array}{l}\text { Females with implan- } \\
\text { tation/recipients }(\%)\end{array}$} & \multirow{2}{*}{$\begin{array}{l}\text { No. and \% } \\
\text { of embryos } \\
\text { implanted }\end{array}$} & \multirow{2}{*}{$\begin{array}{c}\text { Live fetuses } \\
(\%)\end{array}$} & \multirow{2}{*}{$\begin{array}{l}\% \text { of live fetuses in } \\
\text { implanted embryos }\end{array}$} & \multicolumn{2}{|c|}{ Sex of fetuses } \\
\hline & & & & & & $\sigma^{x}$ & 우 \\
\hline \multicolumn{8}{|l|}{ (a) Half-embryo } \\
\hline$\sigma^{\prime}$ & 43 & $2 / 3(67)$ & $19(44)^{a}$ & $5(12)^{\mathrm{e}}$ & 26 & 5 & 0 \\
\hline 우 & 45 & $1 / 3(33)$ & $5(11)^{b}$ & $0(0)^{\mathrm{f}}$ & 0 & 0 & 0 \\
\hline Total & 88 & $3 / 6(50)$ & $24(27)^{c}$ & $5(6)^{\mathrm{g}}$ & 21 & 5 & 0 \\
\hline \multicolumn{8}{|l|}{$\begin{array}{l}\text { (b) Recombined }{ }^{1)} \\
\text { embryo }\end{array}$} \\
\hline$\sigma^{x}+\sigma^{\prime \prime}$ & 35 & $3 / 3(100)$ & $23(66)$ & $5(14)$ & 22 & 5 & 0 \\
\hline 우 + 우 & 31 & $3 / 3(100)$ & $26(84)$ & $7(23)$ & 27 & 0 & 7 \\
\hline Total & 66 & $6 / 6(100)$ & $49(74)^{\mathrm{d}}$ & $12(18)^{\mathrm{h}}$ & 24 & 5 & 7 \\
\hline
\end{tabular}

All blastocysts were transferred into the uteri of Day 4 pseudopregnant mice. Autopsy was made and fetuses were analyzed for gonadal sex on day 18 of gestation. 1) The recombined embryos were produced by aggregating 2 male or female half-embryos in the presence of PHA before compaction occurred. a vs. b, c vs. d $\mathrm{P}<0.01$; e vs. f, g vs. h $\mathrm{P}<0.025$. Values are for 3 replicates.

of the diploid blastomeres were able to be sexed, 281 males and 247 females being identified. Males accounted for $53 \%$.

In vitro development of single blastomeres separated from 2-cell stage embryos

Single blastomeres separated from 2-cell embryos were cultured individually to avoid aggregation between blastomeres. A total of 413 single blastomeres of the 2-cell embryos were subjected to culture, and 389 (94\%) developed to the 2-cell stage $48 \mathrm{~h}$ after insemination. At 72 and $96 \mathrm{hr}, 360(87 \%)$ and $339(82 \%)$ of the single blastomeres developed into morulae and blastocysts, respectively (Table 2; Fig. 2).

The viability of sex-known blastocysts after transferring to recipient mice

Blastocysts developed from single blastomeres of 2-cell embryos were transferred into the uteri of Day 4 recipient mice $96 \mathrm{~h}$ after insemination. At the time of transfer, the sex of these embryos had been identified by karyotyping the other corresponding blastomeres at the 2-cell stage. The transfer results are shown in Table 3. Of 43 male and 45 female half-embryos, $19(44 \%)$ and $5(11 \%)$ were implanted and 5 male half-embryos developed into live fetuses. All of them proved to be male when their gonads were examined.

As the viability of the half-embryos was quite low, a control transfer experiment was conducted. Two sex-known male or female half-embryos were aggregated together and the recombined embryos were transferred into recipient mice $96 \mathrm{~h}$ post-
Table 4. Comparison of number of component blastomeres in male and female halfembryos at 72 and $96 \mathrm{~h}$ post-insemination

\begin{tabular}{lcc}
\hline sex of & \multicolumn{2}{c}{ Mean no. and SD of cells per embryo } \\
\cline { 2 - 3 } embryos & Morula at $72 \mathrm{~h}$ & Blastocyst at $96 \mathrm{~h}$ \\
\hline Male & $\begin{array}{c}7.73 \pm 1.92 \\
(\mathrm{n}=41)\end{array}$ & $\begin{array}{c}22.69 \pm 5.28^{\mathrm{a})} \\
(\mathrm{n}=42)\end{array}$ \\
Female & $\begin{array}{c}8.14 \pm 1.66 \\
(\mathrm{n}=35)\end{array}$ & $\begin{array}{c}18.46 \pm 3.88^{\mathrm{b})} \\
(\mathrm{n}=26)\end{array}$ \\
\hline
\end{tabular}

a vs. $b \quad P<0.01$. The total numbers of embryos determined in each item are shown in parentheses. Datas are for 4 replicates.

insemination (Table 3). Of 66 recombined embryos, 49 were implanted, and 5 male and 7 female live fetuses were obtained with sex identical to that diagnosed before embryo transfer. The implantation rate and the rate of development into live fetuses in recombined embryos were significantly higher than those in the half-embryos $(\mathrm{P}<0.01, \mathrm{P}<0.025)$. But there was no significant difference in the proportion of live fetuses to implanted embryos in recombined (12/49) and half $(5 / 24)$ embryos.

\section{The difference between male and female embryos} in vitro developmental potential

Since the implantation rate was significantly higher in male half-embryos $(\mathrm{P}<0.01)$, and all of the 5 living fetuses from sexed half-embryos were male (Table 3), we examined whether male halfembryos would have a higher developmental 
potential when male and female embryos were cultured in vitro under identical conditions. In the morula stage ( $72 \mathrm{~h}$ post-insemination), there was no significant difference between the 2 types of embryo in the number of component blastomeres. However, in the blastocyst stage $(96 \mathrm{~h}$ postinsemination), the male half-embryos contained significantly more blastomeres per embryo than the female half ones $(22.69: 18.46, \mathrm{P}<0.01$; Table $4)$.

\section{Discussion}

Experiments on sexing of mouse preimplantation embryos and subsequent transfer of the sex-known embryos have been made with numerous approaches. Detection of the H-Y antigen $[12,13]$, determination of X-chromosomelinked enzymes [14] and enzymatic amplification of male specific repeated DNA [15] have been used to sex embryos at least in the 8-cell stage. However, evidence has shown that in the mouse the activation of the embryonic genome started in the 2-cell stage of the embryo [16] and male specific $\mathrm{H}-\mathrm{Y}$ antigen was reported to be expressed in the 8-cell stage and after [17]. For the purpose of studies on embryonic development and sexual differentiation of the mammalian embryo, it is therefore considered to be necessary to sex embryos in an earlier stage.

In ordinary strains of the mouse, the Ychromosome is similar in size to the 19th chromosome, i.e., the smallest autosome. The embryos bearing 3 smallest chromosomes were classified as males if the chromosome preparations were conventionally Giemsa-stained $[9,10]$. But it is sometimes difficult to distinguish between males and females by this method, owing to the inappropriate constriction of chromosomes, if C-banding stain $[10,18]$ is not performed. In the case of $Y^{\text {del }}$ mouse, however, the Y-chromosome is distinctly smaller than half the smallest autosome [19], thus facilitating the discrimination of male from female embryos without requiring time to produce the C-band.

Comparison after transfer of the viability of half and recombined embryos showed that although the implantation rate and the rate of development into live fetuses were significantly higher in the latter, there was no significant difference between the two types of embryo in the proportion of live fetuses to implanted embryos. This implies that the reduction in embryo size or number of component blastomeres resulted in low viability in half-embryos by directly influencing the implantation of embryos. In addition, the low viability might be partly due to the use of in vitro fertilized eggs, since the rate of development of halfembryos in this study was lower than those reported in studies in which in vivo fertilized eggs were used [20, 21].

The results of half-embryo transfer reveal that all of the 5 living fetuses from sexed half-embryos were male, while none of the 45 female halfembryos developed into live fetuses, and the implantation rate was also significantly higher in the male half embryos. On the other hand, similar developmental rates were observed in both male and female recombined embryos, in which 2 half-embryos of the same sex were aggregated. These observations and the fact that the male half-embyos contained more blastomeres in the blastocyst stage than female ones suggest that the failure of the female half-embryos to develop into fetuses was not due to the damage caused by blastomere separation and culture, but due to difference(s) between male and female halfembryos in the developmental potential. Previous experiments have shown that after transfer of 2 groups of the mouse blastocyst embryos, fast cleavers included an excess of males, and slow cleavers more females [22]. From 67 mouse embryos from 10 litters collected on Day 9 of gestation, it was found that there was a sex difference in the stage attained [23]. Females were less developed on the whole and males were more developed, and on average at the time of examination males had 2 somites more than females. These investigations reveals that the sex effect is manifest before gonadal differentation which was visible on day 12.5 post coitum [4], suggesting the possibility that sex-linked genes controlling the rate of cell division are expressed in an early stage embryo. It is therefore considered that further investigating this sex effect with sex-predicted embryos will have great significance in the study of embryonic development and the mechanisms of sex determination and differentiation of mammals. 


\section{Acknowledgment}

This study was supported in part by grants
63640003 and 02151063 from the Ministry of Education, Science and Culture, Japan.

\section{References}

1. Goodfelow PN, Darling SM. Genetics of sex determination in man and mouse. Development 1988; 102: 251-258.

2. Bianchi NO. Sex determination in mammals. How many genes are involved? Biol Reprod 1991; 44: 393-397.

3. Jost A. Vigier B, Prepin J, Perchellet JP. Studies on sex differentiation in mammals. Rec Prog Hor Res 1973; 29: 1-41.

4. Gubbay J, Collignon J, Koopman P, Capel B, Economou A, Munsterberg A, Vivian N, Goodfellow $\mathbf{P}$, Lovell-Badge $\mathbf{R}$. A gene mapping to the sex determining region of the mouse $\mathrm{Y}$-chromosome is a novel family of embryonically expressed genes. Nature 1990; 346: 245-250.

5. Moriwaki K, Sakakibara K. B 10BR mouse with a partially deleted Y-chromosome. Annual Report of National Institute of Genetics (Japan) 1976; 26: 38.

6. Toyoda Y, Yokoyama M, Hosi T. Studies on the fertilization of mouse eggs in vitro I. In vitro fertilization of eggs by fresh epididymal spermatozoa. Japan J Anim Reprod 1971; 16: 147-151.

7. Whitten WK. Nutritional requirements for the culture of preimplantation embryos in vitro. Adv in Biosci 1971; 6: 129-139.

8. Hoshi M. Toyoda Y. Effect of EDTA on the preimplantation development of mouse embryos fertilized in vitro. Jpn J Zootech Sci 1985; 56: 931-937.

9. Tarkowski AK. An air dry method for chromosome preparations from mouse eggs. Cytogenetics 1965; 5: 394-400.

10. Evans EP. Karyotyping and sexing of gametes, embryos and fetuses and in situ hybridization to chromosomes. In: Monk M (ed) Mammalian Development-A Practical Approach. Oxford: IRL Press; 1987: 93-114.

11. Hogan B, Costantini F, Lacy E. Manipulating the Mouse Embryos: A Laboratory Mannual. New York: Cold Spring Harbor Press; 1986: 271.

12. White KL, Lindner Fm, Anderson GB, BonDurant RH. Survival after transfer of sexed mouse embryos exposed to H-Y antisera. Theriogenology 1982; 18: 655-662.
13. White KL, Lindner FM, Anderson GB, BonDurant RH. Cytolytic and fluorescent detection of $\mathrm{H}-\mathrm{Y}$ antigen on preimplantation embryos. Theriogenology 1983; 19: 701-705.

14. Monk M, Handyside AH. Sexing of preimplantation mouse embryos by measurement of X-linked gene dosage in a single blastomere. J Reprod Fert 1988; 82: 365-368.

15. Bradbury MW, Isola LM, Gordon JW. Enzymatic amplification of a Y-chromosome repeat in a single blastomere allows identification of the sex of preimplantation mouse embryos. Proc Natl Acad Sci USA 1990; 87: 4053-4057.

16. Flach G, Johnson MH, Braude PR, Taylor RAS, Bolton $\mathbf{V}$. The transition from maternal to embryonic control in the 2-cell mouse embryos. EMBO J 1982; 1: 681-686.

17. Krco CJ, Goldberg EH. H-Y (male) antigen: detection on eight-cell mouse embryos. Science 1976; 193: 1134-1135.

18. Yoshizawa M, Muramatsu T, Okamoto A. Sexing of mouse eggs at the first cleavage division by the use of C-staining method. Japan J Anim Reprod 1985; 31: 78-83.

19. Styrna J, Imai H, Moriwaka K. An increased level of sperm abnormalities in mice with a partial deletion of the Y chromosome. Genet Res Camb 1991; 57: 195-199.

20. Togashi M, Suzuki H, Miyai T, Okamoto MT. Production of monozygotic twins by splitting of 2-cell stage embryos in mice. Japan J Anim Reprod 1987; 33: 51-57.

21. Kono $\mathbf{T}$, Ogawa $\mathbf{M}$, Ichinoe $\mathbf{K}$, Nakahara $\mathbf{T}$. Development of mouse half embryos produced by micromanipulation at the two cell stage. Japan J Anim Reprod 1990; 36: 164-170.

22. Tsunoda $\mathbf{Y}$, Tokunaga $\mathbf{T}$, Sugie $\mathbf{T}$. Altered sex ratio of live young after transfer of fast- and slow-developing mouse embryos. Gamete Res 1985; 12: 301-304.

23. Seller MJ, Perkins-Cole LJ. Sex difference in mouse embryonic development at neurulation. $J$ Reprod Fert 1987; 79: 159-161. 